\title{
Identification of immunoreactive proteins of Brucella melitensis by immunoproteomics
}

\author{
ZHAO ZhongPeng ${ }^{1 \dagger}$, YAN Fang ${ }^{2 \dagger}$, JI WenHui $^{2}$, LUO DeYan $^{1}$, LIU Xin $^{1}$, XING $^{1}{ }^{1}$, \\ DUAN YueQiang ${ }^{1}$, YANG PengHui ${ }^{1}$, SHI XiuMin ${ }^{2}$, LI Zhong $^{2}$ \& WANG XiLiang ${ }^{1 *}$ \\ ${ }^{1}$ State Key Laboratory of Pathogen and Biosecurity, Beijing Institute of Microbiology and Epidemiology, Beijing 100071, China; \\ ${ }^{2}$ College of Animal Science and Veterinary Medicine, Shanxi Agricultural University, Taigu 030801, China
}

Received March 27, 2011; accepted July 20, 2011

\begin{abstract}
Infection with Brucella causes brucellosis, a chronic disease in humans, which induces abortion and sterility in livestock. Among the different Brucella species, Brucella melitensis is considered the most virulent and is the predominant species associated with outbreaks in China. To date, no safe human vaccine is available against Brucella infection. The currently used live vaccines against Brucella in livestock induce antibodies that interfere with the diagnosis of field infection in vaccinated animals, which is harmful to eradication programs. However, there is as yet no complete profile of immunogenic proteins of $B$. melitensis. Towards the development of a safer, equally efficacious, and field infection-distinguishable vaccine, we used immunoproteomics to identify novel candidate immunogenic proteins from B. melitensis M5. Eighty-eight immunoreactive protein spots from B. melitensis M5 were identified by Western blotting and were assigned to sixty-one proteins by mass spectrometry, including many new immunoreactive proteins such as elongation factor G, F0F1 ATP synthase subunit beta, and OMP1. These provide many candidate immunoreactive proteins for vaccine development.
\end{abstract}

Brucella, immunoproteomics, immunoreactive protein

Citation: Zhao Z P, Yan F, Ji W H, et al. Identification of immunoreactive proteins of Brucella melitensis by immunoproteomics. Sci China Life Sci, 2011, 54: 880-887, doi: 10.1007/s11427-011-4218-2

Brucella are Gram-negative, nonspore-forming, nonmotile, and nonencapsulated coccobaccilli that occasionally cause brucellosis, also known as undulant fever, a chronic and debilitating febrile disease in humans that frequently induces abortion and sterility in domestic and wild animals. $\mathrm{Hu}-$ man infection can result from either occupational contact or ingestion of contaminated food [1]. The incidence of human and animal brucellosis worldwide has increased rapidly since 1995. In China, B. melitensis is the predominant strain associated with outbreaks [2].

Based on pathogenicity and host preference, eight species have been identified within the genus: B. melitensis, $B$.

$\uparrow$ Contributed equally to this work

*Corresponding author (email: xiliangw@126.com) abortus, B. suis, B. canis, B. cetacea, B. pinnipedia, B. neotomae, and B. ovis [3]. Humans can become infected with $B$. melitensis, B. abortus, B. suis, and rarely, B. canis, B. pinnipedia, and B. cetacea. Among the different Brucella species, $B$. melitensis is considered the most virulent.

In livestock, brucellosis used to be partly controlled by conventional vaccines. Live, attenuated vaccines such as M5 and S2 have been used in animals in China; however, they are considered unsafe for humans as they can induce abortion in pregnant animals [2]. Development of the next generation of vaccines that are free from the drawbacks of the conventional vaccines requires the identification of Brucella antigens that can elicit a protective immune response [4].

The diagnosis of brucellosis is mainly based on the de- 
tection of anti-lipopolysaccharide antibodies, and the currently used live vaccines against Brucella in livestock induce high amounts of anti-lipopolysaccharide antibodies that interfere with the diagnosis of field infection in vaccinated animals [5]. Hence, the development of diagnostic assays based on more specific protein antigens is essential. It is very important that the live vaccines are revised to target a specific diagnostic protein antigen, which can distinguish field infection and have no effects on their protective efficacy in vaccinated animals.

Unfortunately, a definitive profile of immunogenic proteins, especially the Brucella protective proteins, is not yet complete [6,7]. However, much of this information can be derived from immunoproteomics, a technique that shows promise for diagnostics and vaccine development [8,9]. Moreover, the sequencing and annotation of pathogen genomes paves the way for the identification of immunogenic proteins [10-12]. Initial work describing the Brucella proteome and immunoproteomics has been reported. A global proteomic analysis of whole cells of B. melitensis 16M [13] and a comparative proteomic analysis of Rev 1 and 16M [14] have been performed; recently, immunoreactive soluble proteins of $B$. melitensis $16 \mathrm{M}$ have been identified by immunoproteomics using the sera of patients suffering from acute brucellosis [15]. Proteins that are located in the outer membrane of the cell envelope are of special interest since they can modify the host cell environment and mediate host cell-bacterial interactions [16]. Accumulated data have indicated that the major protective antigens appear to be components of the cell envelope [6]. Here, using bovine anti-Brucella sera, the whole-cell soluble proteins and membrane proteins (MPs) were screened, and 88 protein spots from $B$. melitensis M5 were identified to be immunoreactive.

\section{Materials and methods}

\subsection{Bacterial cell culture}

B. melitensis M5, a biotype I vaccine strain, was used. Stock samples stored at $-70^{\circ} \mathrm{C}$ were inoculated in Tryptic Soy Broth (Becton Dickinson Company, Sparks, USA) and incubated to stationary growth phase by vigorous shaking for $16 \mathrm{~h}$ at $37^{\circ} \mathrm{C}$.

\subsection{Isolation of whole-cell soluble proteins [17]}

Cells from 200-mL cultures in the stationary growth phase were harvested by centrifugation at $4000 \times g$ for $15 \mathrm{~min}$ at $4^{\circ} \mathrm{C}$. The pellets were washed twice with low-salt washing sample buffer $\left(3 \mathrm{mmol} \mathrm{L}{ }^{-1} \mathrm{KCl}, 1.5 \mathrm{mmol} \mathrm{L}{ }^{-1} \mathrm{KH}_{2} \mathrm{PO}_{4}, 68\right.$ mmol L ${ }^{-1} \mathrm{NaCl}, 9 \mathrm{mmol} \mathrm{L}-1 \mathrm{NaH}_{2} \mathrm{PO}_{4}$ ) and resuspended in sonication buffer $\left(8 \mathrm{~mol} \mathrm{~L}^{-1}\right.$ urea, $1 \%$ dithiothreitol, $4 \%$ CHAPS, $100 \mathrm{U}$ Benzonase, and a tablet of complete prote- ase inhibitor cocktail) and then sonicated on ice. The solution was kept at room temperature for $1 \mathrm{~h}$ and centrifuged at $12000 \times g$ for $1 \mathrm{~h}$. The supernatant was collected and stored at $-70^{\circ} \mathrm{C}$.

\subsection{Isolation and purification of MPs [18]}

After washing, harvested cells were resuspended in $100 \mathrm{~mL}$ buffer I (15 mmol L ${ }^{-1}$ Tris- $\mathrm{HCl} \mathrm{pH} 8.0,0.45 \mathrm{~mol} \mathrm{~L}^{-1}$ sucrose, $8 \mathrm{mmol} \mathrm{L}^{-1}$ EDTA, and $0.4 \mathrm{mg} \mathrm{mL}^{-1}$ lysozyme). The samples were incubated for $4 \mathrm{~h}$ at $4^{\circ} \mathrm{C}$, centrifuged at $8000 \times g$ for $15 \mathrm{~min}$, and resuspended in $3 \mathrm{~mL}$ buffer II $(50$ mmol L ${ }^{-1}$ Tris- $\mathrm{HCl} \mathrm{pH} 7.4$ and a tablet of complete protease inhibitor cocktail). The samples were chilled on ice and sonicated. Then the samples were centrifuged twice at $3000 \times g$ for $15 \mathrm{~min}$ to remove unbroken cells. Chilled 0.1 mol L ${ }^{-1} \mathrm{Na}_{2} \mathrm{CO}_{3}$, pH 11.0 (27 mL) was added to the supernatants, and they were vortexed and immersed in ice water for $1 \mathrm{~h}$. The supernatants were then subjected to ultracentrifugation at $50000 \times g$ for $1 \mathrm{~h}$. The pellets were resuspended in $20 \mathrm{~mL}$ buffer II and ultracentrifuged again at $50000 \times g$ for $1 \mathrm{~h}$. The pellets were resuspended in sample buffer $(8 \mathrm{~mol}$ $\mathrm{L}^{-1}$ urea, $1 \%$ dithiothreitol, $4 \%$ CHAPS, and a tablet of complete protease inhibitor cocktail) and stored at $-70^{\circ} \mathrm{C}$ until required.

\subsection{Protein determination}

The total protein concentration was determined using a Bradford kit (Applygen Technologies, Inc., Beijing, China) with bovine serum albumin as the standard. All samples, including the standard, were dissolved in the same buffer.

\subsection{Western blotting}

The sample proteins $(200 \mu \mathrm{g})$ were separated by isoelectric focusing on 18-cm, $\mathrm{pH} 4-7$ linear immobilized $\mathrm{pH}$ gradient (IPG) strips. After $12 \mathrm{~h}$ of rehydration at $30 \mathrm{~V}$ and $20^{\circ} \mathrm{C}$, the following focusing parameters were applied: $50 \mu \mathrm{A}$ per strip, with 500,2000 , or $5000 \mathrm{~V}$ for $30 \mathrm{~min}$, linear voltage increased from 5000 to $10000 \mathrm{~V}$ in $2 \mathrm{~h}$, then maintained at $10000 \mathrm{~V}$ for $8 \mathrm{~h}$. After isoelectric focusing, IPG strips were equilibrated and applied onto $12 \%$ vertical slab SDS-polyacrylamide gels of $19 \times 18.5 \times 0.1 \mathrm{~cm}^{3}$. Electrophoresis was performed at $20^{\circ} \mathrm{C}$ with a constant power supply in two steps: $20 \mathrm{~mA} / \mathrm{gel}$ for $30 \mathrm{~min}$ then $30 \mathrm{~mA} / \mathrm{gel}$ until the tracking dye reached the bottom of the gel. Gels were then stained with Coomassie Brilliant Blue R-250. The gels were scanned with an Imagescanner, and the images analyzed using version 5.0 of ImageMaster 2D Platinum software.

Proteins were transferred to polyvinylidene fluoride membranes using a TE77 semi-dry transfer unit $(0.8 \mathrm{~mA}$ $\mathrm{cm}^{-2}, 1 \mathrm{~h}$ ), then non-specific binding sites on the membranes were blocked for 90 min with $5 \%$ skimmed milk in Tris-buffered saline (TBS) at $37^{\circ} \mathrm{C}$. Then, the membranes 
were probed with a 1:1500 dilution of primary antibody for $1 \mathrm{~h}$ at $37^{\circ} \mathrm{C}$ with gentle shaking. The primary antibody was a bovine anti-Brucella-positive serum pool, which was a mixture of 15 bovine anti-Brucella-positive sera with titers of more than $1: 1600$ by tube agglutination tests. The cows had never been immunized with any Brucella vaccine. The control antibody was an anti-Brucella-negative bovine serum pool, which was a mixture of 23 anti-Brucella-negative bovine sera with tube agglutination titers of less than $1: 10$. The membranes were rinsed three times for $10 \mathrm{~min}$ each in $0.1 \%$ TBS plus Tween 20, then incubated with peroxidase-conjugated rabbit anti-bovine immunoglobulin at a dilution of $1: 10000$ in TBS containing 5\% skimmed milk for $1 \mathrm{~h}$ at $37^{\circ} \mathrm{C}$. After washing, the blots were developed using enhanced chemiluminescence Western blotting detection reagents. The specific immunoreactive protein pattern was visualized on X-ray film. Three replicate blots were used for image analysis.

\subsection{In situ tryptic digestion, mass spectrometry (MS), and protein identification}

Coomassie-stained protein spots were excised from the gel and destained with $25 \mathrm{mmol} \mathrm{L}^{-1}$ ammonium bicarbonate buffer containing $50 \%$ acetonitrile. The destained gel pieces were completely dried then rehydrated with $2 \mu \mathrm{L}$ of 20 mmol L ${ }^{-1}$ ammonium bicarbonate containing $20 \mathrm{ng}$ trypsin. After overnight incubation at $37^{\circ} \mathrm{C}$, the gels were dried then incubated at $40^{\circ} \mathrm{C}$ for $1 \mathrm{~h}$ in $8 \mu \mathrm{L}$ of $5 \%$ trifluoroacetic acid (TFA). The extract was transferred into a fresh microtube. A second, 1-h extraction step was performed at $30^{\circ} \mathrm{C}$ in $8 \mu \mathrm{L}$ of $2.5 \%$ TFA $/ 50 \%$ acetonitrile, then the two extracts were combined, dried, and resolubilized with $3 \mu \mathrm{L}$ of $0.1 \%$ TFA.

Matrix-assisted laser desorption/ionization-time-of-flight (MALDI-TOF) MS measurements were performed on a Bruker Reflex ${ }^{\mathrm{TM}}$ III instrument (Bruker Daltonik, Bremen, Germany) operating in reflection mode. The MALDI-TOFMS analysis was performed at $20 \mathrm{kV}$ accelerating voltage and $23 \mathrm{kV}$ reflecting voltage. The peptide mass fingerprints were searched against the NCBInr database using the Mascot search engine (http://www.matrixscience.com/search_ form_select.html). The search parameters used were: maximum of one missed cleavage by trypsin; oxidation of methionine; carbamidomethyl modification of cysteine; charged state of +1 ; and mass tolerance of \pm 0.1 Da. Probability-based MOWSE scores greater than 75 were considered significant $(P<0.05)$. For unambiguous identification of proteins, more than five peptides had to be matched and the sequence coverage had to be greater than $15 \%$.

\section{Results}

Typical gel maps of the whole-cell soluble proteins and MPs are presented in Figures 1A and 2A. A total of 725 and

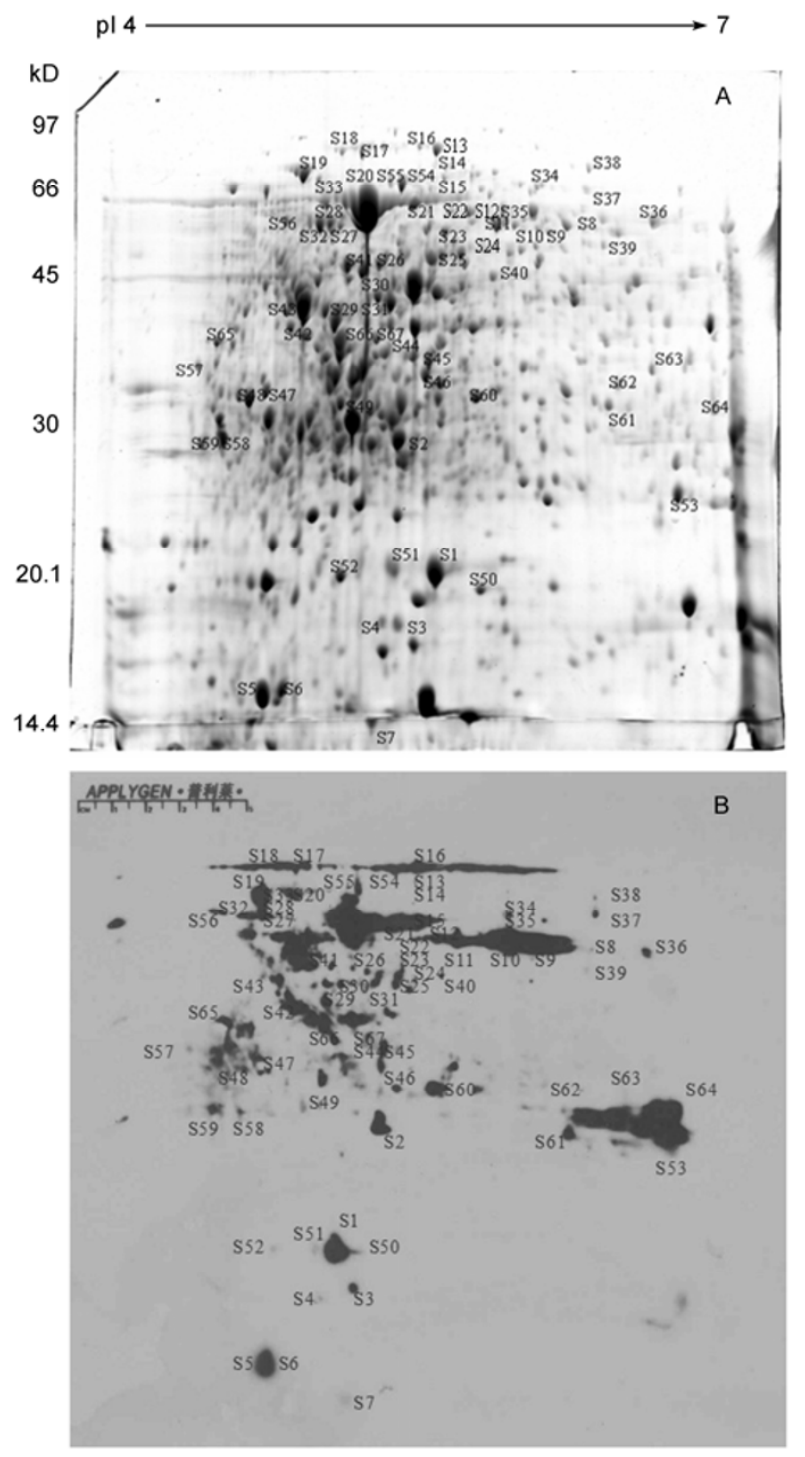

Figure 1 The proteome and Western blot of soluble proteins of $B$. melitensis $\mathrm{M} 5$ in the $\mathrm{pH}$ range 4.0-7.0. A, Soluble proteins $(200 \mu \mathrm{g})$ were focused with IPG strips and run on $12 \%$ SDS-polyacrylamide gels. The gels were stained with Coomassie Brilliant Blue R250 and scanned. B, The primary antibody was a 1:1500 dilution of a bovine anti-Brucella-positive serum pool. The immunoreactive spots detected by Western blotting are marked. No spots were positive for the control primary antibody.

426 protein spots were detected for the whole-cell soluble proteins and MPs, respectively. Of these, 67 and 21 spots, respectively, were immunoreactive with the bovine anti-Brucella-positive serum pool compared with the control anti-Brucella-negative serum pool (data not shown). These spots were named $\mathrm{S} 1$ to $\mathrm{S} 67$ and $\mathrm{O} 1$ to $\mathrm{O} 21$, respectively (Figures 1B and 2B, respectively).

Seventy-nine proteins, representing the products of 61 genes, were successfully identified. Tables 1 and 2 list the identified proteins from the whole-cell soluble protein and MP samples, respectively. According to TIGR function categories, these immunoreactive proteins are mainly involved in protein fate (10/61), transport and binding (8/61), 

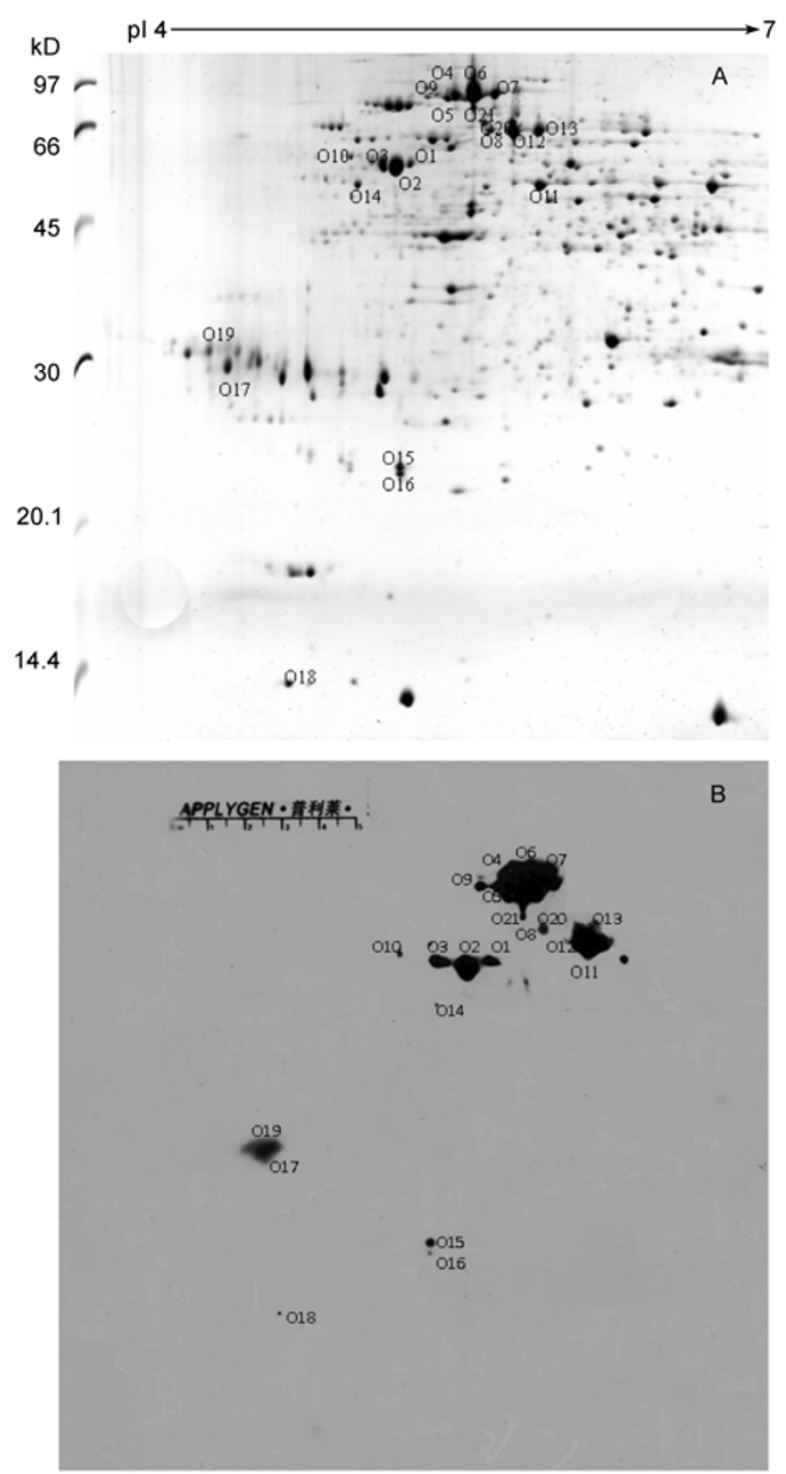

Figure 2 The proteome and Western blot of MPs of B. melitensis M5 in the $\mathrm{pH}$ range 4.0-7.0. A, MPs $(200 \mu \mathrm{g})$ were focused with IPG strips and run on $12 \%$ SDS-polyacrylamide gels. The gels were stained with Coomassie Brilliant Blue R250 and scanned. B, The primary antibody was a $1: 1500$ dilution of a bovine anti-Brucella-positive serum pool. The immunoreactive spots detected by Western blotting are marked. No spots were positive for the control primary antibody.

energy metabolism (8/61), protein synthesis (6/61), and cellular processes (4/61). Among the 61 identified proteins, ten were theoretical cell envelope proteins. Interestingly, the immunoreactive proteins included eight known virulence-related proteins, including OMP25, trigger factor, DnaK, glucose-6-phosphate 1-dehydrogenase, SSU ribosomal protein S1P, glutamine synthetase type I, acetolactate synthase 3 catalytic subunit, and threonine synthase [19].

\section{Discussion}

There is a pressing need to develop novel vaccines and spe- cific diagnostic assays to reduce the high incidence of brucellosis worldwide. In this study, we used an immunoproteomic screen to identify many candidate $B$. melitensis antigens for these purposes.

Using immunoproteomics greatly improves the chances of discovering immunogenic proteins. We identified 61 immunoreactive proteins in this study, many more than the 32 proteins that were discovered in early protein studies using Edman sequencing or Western blotting before the genomes of the Brucella species had been completely sequenced [7]. To further improve the chances of identifying novel antigens, we carried out sub-proteomics. Besides the four common antigens, the MP sample contained eight antigens that were not identified in the whole-cell soluble protein sample; this indicates that sub-proteomics can be used to decrease the complexity of the whole-cell soluble protein sample to improve the discovery of novel antigens [20].

Immunoproteomics has several drawbacks such that it cannot be used to identify all the immunoreactive proteins of Brucella. For example, the Brucella lumazine synthase protein has never been identified by immunoproteomics, but is known to be able to elicit an immune and protective response against Brucella [21]. More importantly, different research groups have discovered very different spectra of immunoreactive proteins using immunoproteomics, because of the different protein samples and anti-Brucella sera used. For example, using an unabsorbed anti-B. abortus 1119-3 killed whole-cell rabbit serum, Al Dahouk et al. [5] identified 17 immunoreactive protein spots out of the 383 protein spots of B. abortus 1119-3, which were assigned to six proteins. In contrast, Teixeira-Gomes et al. [22] were able to identify 82 immunoreactive protein spots in a comparable protein sample preparation of $B$. ovis using the serum of a naturally infected ram. In another study, using antiserum collected from cows and a human accidentally infected with Brucella, 54 immunoreactive protein spots out of 332 protein spots in $B$. abortus $\mathrm{CE}$ were identified, which were assigned to 18 proteins [6]. Recently, 32 immunoreactive protein spots assigned to 27 proteins among the soluble proteins of $B$. melitensis $16 \mathrm{M}$ were identified using the sera of patients suffering from acute brucellosis [15]. In this study, we identified 88 immunoreactive protein spots assigned to 61 proteins out of 1151 protein spots. The higher number of proteins we identified suggests that using an antiBrucella-positive serum pool can improve the chances of identification. Of the 61 immunoreactive proteins in our study, only 4, 5, 9, and 3 proteins are in common with those identified by Al Dahouk et al. [5], Teixeira-Gomes et al. [22], Connolly et al. [6], and Yang et al. [15], respectively. Therefore, all the proteins identified by immunoproteomics need further validation and evaluation by other groups and methods. Of course, live Brucella dynamically adjusts its protein expression profile for survival in the host and it may change enormously during the course of infection [23]. Some proteins may not be expressed under laboratory con- 
Table 1 Immunoreactive soluble proteins from $B$. melitensis M5 as determined by Western blotting and MALDI-TOF-MS

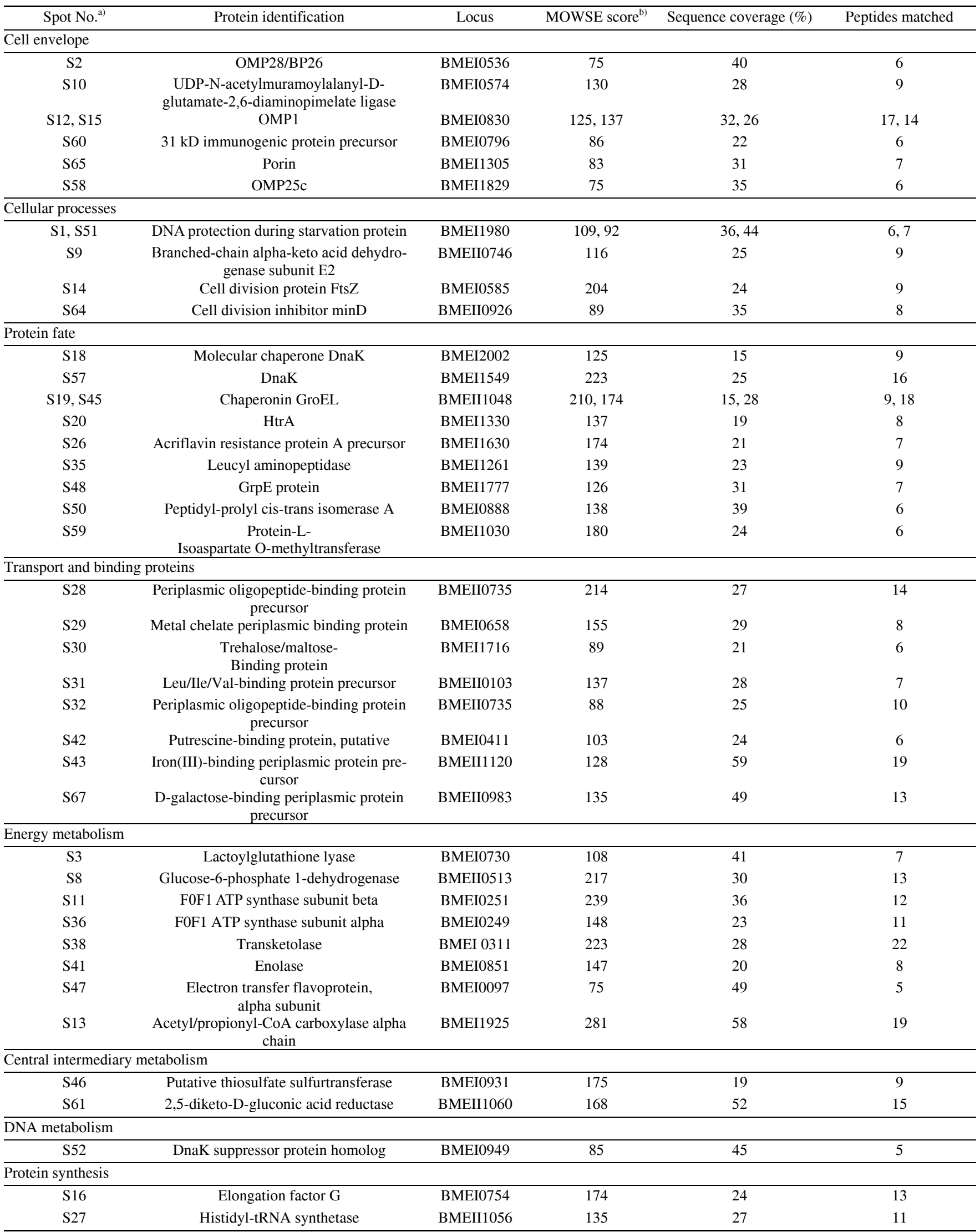




\begin{tabular}{|c|c|c|c|c|c|}
\hline Spot No. $^{\text {a) }}$ & Protein identification & Locus & MOWSE score ${ }^{\text {b) }}$ & Sequence coverage $(\%)$ & Peptides matched \\
\hline S53 & Ribosome recycling factor & BMEI0826 & 95 & 41 & 6 \\
\hline S55 & SSU ribosomal protein S1P & BMEI1915 & 116 & 16 & 9 \\
\hline S66 & $\begin{array}{l}\text { Protein translation elongation factor Ts } \\
\text { (EF-Ts) }\end{array}$ & BMEI0824 & 157 & 64 & 16 \\
\hline \multicolumn{6}{|c|}{ Amino acid biosynthesis } \\
\hline $\mathrm{S} 21$ & Glutamine synthetase type I & BMEI0979 & 213 & 25 & 11 \\
\hline $\mathrm{S} 24$ & Threonine synthase & BMEI1450 & 179 & 57 & 15 \\
\hline \multicolumn{6}{|c|}{ Biosynthesis of cofactors, prosthetic groups and carriers } \\
\hline $\mathrm{S} 40$ & $\begin{array}{c}\text { GTP cyclohydrolase } \\
\text { II/3,4-dihydroxy-2-butanone 4-phosphate } \\
\text { synthase }\end{array}$ & BMEI1505 & 145 & 42 & 17 \\
\hline S62 & $\begin{array}{l}\text { 2,3,4,5-tetrahydropyridine-2-carboxylateN- } \\
\text { succinyltransferase }\end{array}$ & BMEII0270 & 99 & 16 & 5 \\
\hline S23 & 3-oxoacyl-(acyl carrier protein) synthase II & BMEI1473 & 136 & 51 & 13 \\
\hline S39 & $\begin{array}{l}\text { Acetyl-CoA carboxylase biotin carbox- } \\
\text { ylase }\end{array}$ & BMEI1063 & 157 & 39 & 12 \\
\hline S63 & $\begin{array}{c}\text { Acetyl-CoA carboxylase carboxyltransfer- } \\
\text { ase subunit alpha }\end{array}$ & BMEI0039 & 152 & 34 & 9 \\
\hline \multicolumn{6}{|l|}{ Transcription } \\
\hline $\mathrm{S} 17$ & $\begin{array}{c}\text { Polynucleotide phosphory- } \\
\text { lase/polyadenylase }\end{array}$ & BMEI1961 & 183 & 17 & 9 \\
\hline \multicolumn{6}{|l|}{ Unclassified } \\
\hline S37 & $\begin{array}{l}\text { Electron transfer flavoprotein-ubiquinone } \\
\text { oxidoreductase precursor }\end{array}$ & BMEI1320 & 218 & 31 & 16 \\
\hline \multicolumn{6}{|l|}{ Not determined } \\
\hline $\begin{array}{l}\mathrm{S} 4, \mathrm{~S} 5, \mathrm{~S} 6, \mathrm{~S} 7, \mathrm{~S} 22 \\
\mathrm{~S} 25, \mathrm{~S} 49, \mathrm{~S} 54, \mathrm{~S} 56\end{array}$ & & & & & \\
\hline
\end{tabular}

a) Spot numbers refer to the numbers on the gel shown in Figure 1A. b) Protein scores greater than 75 are significant $(P<0.05)$.

Table 2 Immunoreactive MPs from B. melitensis M5 as determined by Western blotting and MALDI-TOF-MS

\begin{tabular}{|c|c|c|c|c|c|}
\hline Spot No. ${ }^{\text {a) }}$ & Protein identification & Locus & MOWSE score ${ }^{\mathrm{b})}$ & Sequence coverage $(\%)$ & Peptides matched \\
\hline \multicolumn{6}{|l|}{ Cell envelope } \\
\hline $\mathrm{O} 5, \mathrm{O} 6$ & \multirow{2}{*}{ OMP1 } & \multirow{2}{*}{ BMEI0830 } & 114,177 & 46,38 & 36,20 \\
\hline $\mathrm{O} 7, \mathrm{O} 21$ & & & 193,197 & 54,51 & 43,42 \\
\hline $\mathrm{O} 8, \mathrm{O} 12$ & Iron-regulated outer membrane protein FRPB & BMEII0105 & 153,180 & 42,45 & 30,31 \\
\hline O13 & Bacterial surface antigen (D15) & BMEI1895 & 218 & 77 & 40 \\
\hline $\mathrm{O} 15, \mathrm{O} 16$ & OMP 25 & BMEI1249 & 83,101 & 38,62 & 12,16 \\
\hline $\mathrm{O} 17, \mathrm{O} 19$ & OMP25b & BMEI1007 & 76,93 & 25,25 & 5,5 \\
\hline \multirow{2}{*}{$\mathrm{O} 1, \mathrm{O} 2, \mathrm{O} 3$} & \multirow{2}{*}{ Chaperonin GroEL } & \multirow{2}{*}{ BMEII1048 } & 175,128 & 40,43 & 22,23 \\
\hline & & & 108 & 35 & 17 \\
\hline $\mathrm{O} 10$ & Trigger factor & BMEI1069 & 82 & 41 & 23 \\
\hline \multicolumn{6}{|c|}{ Energy metabolism } \\
\hline $\mathrm{O} 11$ & ATP synthase subunit B & BMEI0251 & 128 & 67 & 28 \\
\hline $\mathrm{O} 20$ & Acetyl/propionyl-CoA carboxylase Alpha chain & BMEI1925 & 93 & 38 & 26 \\
\hline \multicolumn{6}{|l|}{ Protein synthesis } \\
\hline $\mathrm{O} 18$ & 50S ribosomal protein & BMEI0748 & 61 & 58 & 5 \\
\hline \multicolumn{6}{|c|}{ Cell envelope biogenesis } \\
\hline O4, O9 & $\begin{array}{c}\text { Organic solvent } \\
\text { Tolerance protein }\end{array}$ & BMEI1264 & 168,150 & 51,51 & 39,42 \\
\hline \multicolumn{6}{|l|}{ Unknown } \\
\hline $\mathrm{O} 14$ & Hypothetical protein & BMEI0178 & 85 & 65 & 11 \\
\hline
\end{tabular}

a) Spot numbers refer to the numbers on the gel shown in Figure 2A. b) Protein scores greater than 75 are significant $(P<0.05)$.

ditions. Furthermore, even under common laboratory conditions, the protein expression profile of $B$. melitensis is different from that of B. abortus [24]. The production of anti- bodies directed against specific proteins may be host-specific. Some proteins are highly immunogenic in one type of animal but fail to show any immunogenicity in other animal 
types. Anti-OMP28 (BP26) antibodies were detected in Brucella-infected humans and goats, but not in pigs and cattle [25]. Additionally, the kinetics of the serum antibody response to Brucella proteins may reflect the different stages of infection. Antibodies to BP26 were found only in the sera of patients suffering from acute brucellosis [26].

The complete profile of immunoreactive proteins will ultimately help to understand the interesting biology of different Brucella species, such as their virulence and host preference. Considering our data and those of Connolly et al. [6], it is likely that the presence of ribosomal proteins in the membrane preparations from prokaryotes genuinely indicates their localization at the membrane, rather than contamination by cytosolic proteins $[27,28]$. OMP25 belongs to the OMP A protein family, which accounts for $30 \%-40 \%$ of the outer membrane. In the genome of $B$. melitensis, four OMP25 genes are predicted: BMEI1249, BMEI1007, BMEI1829, and BMEI1830, of which three (BMEI1249, BMEI1007, and BMEI1829) were identified in this study. Importantly, OMP25 is an immune response regulator and may mediate inhibition of the host cell production of tumor necrosis factor alpha [29]. Mutants of B. melitensis, B. abortus, and B. ovis strains with the OMP25 gene inactivated have been found to be attenuated in mice, goats, and cattle [30-32]. Heat shock proteins are vital for Brucella survival under various harsh conditions; these were identified in almost all immunoproteomic studies. The blockage of heat shock protein function by antibodies may be an important host protection strategy. HtrA is generally thought to serve as a stress response protease in the periplasmic space and has been shown to be important for adaption to the intracellular environment of host macrophages [33,34]. DnaK is important for Brucella growth and survival under stress conditions: A constitutive DnaK mutant failed to multiply in murine macrophages and was rapidly eliminated [35]. Trigger factor is an ATP-independent chaperone that binds to the nascent polypeptide chain [36]. Recently trigger factor was revealed to be a protective antigen against brucellosis [37]. In addition, the proteins involved in energy metabolism, iron acquisition [14], and protein synthesis may be vital for Brucella survival, some of which were also identified to be immunoreactive in this study. Recently, recombinant S-adenosyl-L-homocysteine hydrolase has been shown to stimulate the production of interferon gamma and induce a high level of protection against $B$. melitensis [15].

In summary, we discovered 61 immunoreactive proteins from among the whole-cell soluble proteins and MPs of $B$. melitensis M5. These data will help to develop novel vaccines and specific diagnostic assays in the future. At present, validation of these proteins' immunoreactivity and investigation of their protective efficacy is in progress. Twelve of them have been validated as immunogenic, including the iron-regulated outer membrane protein FRPB (BMEII0105) and grpE protein (BMEI1777). Using anti-Brucella sera collected from animals and humans accidentally infected with different species of Brucella, all the novel immunoreactive proteins of the various Brucella species will gradually be discovered and investigated.

We gratefully thank Jiang SenLin (CDC, Baicheng, China) for providing the serum samples and Janice Willson for assistance in preparing the manuscript. This work was supported by the National Basic Research Program of China (Grant No. 2010CB530200).

1 Corbel M J. Brucellosis: an overview. Emerg Infect Dis, 1997, 3: 213-221

2 Deqiu S, Donglou X, Jiming Y. Epidemiology and control of brucellosis in China. Vet microbiol, 2002, 90: 165-182

3 Jahans K L, Foster G, Broughton E S. The characterisation of Brucella strains isolated from marine mammals. Vet Microbiol, 1997, 57: 373-382

4 Khan A S, Mujer C V, Alefantis T G, et al. Proteomics and bioinformatics strategies to design countermeasures against infectious threat agents. J Chem Inf Model, 2006, 46: 111-115

5 Al Dahouk S, Nockler K, Scholz H C, et al. Immunoproteomic characterization of Brucella abortus 1119-3 preparations used for the serodiagnosis of Brucella infections. J Immunol Methods, 2006, 309: 34-47

6 Connolly J P, Comerci D, Alefantis T G, et al. Proteomic analysis of Brucella abortus cell envelope and identification of immunogenic candidate proteins for vaccine development. Proteomics, 2006, 6: 3767-3780

7 DelVecchio V G, Wagner M A, Eschenbrenner M, et al. Brucella proteomes-a review. Vet microbiol, 2002, 90: 593-603

8 Pizza M, Scarlato V, Masignani V, et al. Identification of vaccine candidates against serogroup B. meningococcus by whole-genome sequencing. Science, 2000, 287: 1816-1820

9 Rappuoli R. Reverse vaccinology, a genome-based approach to vaccine development. Vaccine, 2001, 19: 2688-2691

10 Chain P S, Comerci D J, Tolmasky M E, et al. Whole-genome analyses of speciation events in pathogenic Brucellae. Infect immun, 2005, 73: 8353-8361

11 Paulsen I T, Seshadri R, Nelson K E, et al. The Brucella suis genome reveals fundamental similarities between animal and plant pathogens and symbionts. Proc Natl Acad Sci USA, 2002, 99: 13148-13153

12 DelVecchio V G, Kapatral V, Redkar R J, et al. The genome sequence of the facultative intracellular pathogen Brucella melitensis. Proc Natl Acad Sci USA, 2002, 99: 443-448

13 Wagner M A, Eschenbrenner M, Horn T A, et al. Global analysis of the Brucella melitensis proteome: Identification of proteins expressed in laboratory-grown culture. Proteomics, 2002, 2: 1047-1060

14 Eschenbrenner M, Wagner M A, Horn T A, et al. Comparative proteome analysis of Brucella melitensis vaccine strain Rev 1 and a virulent strain, 16M. J Bacteriol, 2002, 184: 4962-4970

15 Yang Y, Yin J, Guo D, et al. Immunization of mice with recombinant S-adenosyl-L-homocysteine hydrolase protein confers protection against Brucella melitensis infection. FEMS Immunol Med Microbiol, 2011, 61: 159-167

16 Celli J, Gorvel J P. Organelle robbery: Brucella interactions with the endoplasmic reticulum. Curr Opin Microbiol, 2004, 7: 93-97

17 Peng X, Ye X, Wang S. Identification of novel immunogenic proteins of Shigella flexneri 2a by proteomic methodologies. Vaccine, 2004, 22: 2750-2756

18 Ying $\mathrm{T}$ Y, Wang J J, Wang H L, et al. Immunoproteomics of membrane proteins of Shigella flexneri 2a 2457T. World J Gastroenterol, 2005, 11: 6880-6883

19 Delrue R M, Lestrate P, Tibor A, et al. Brucella pathogenesis, genes identified from random large-scale screens. FEMS Microbiol Lett, 2004, 231: 1-12

20 Patton W F. Proteome analysis. II. Protein subcellular redistribution: linking physiology to genomics via the proteome and separation technologies involved. J Chromatogr, 1999, 722: 203-223 
21 Velikovsky C A, Goldbaum F A, Cassataro J, et al. Brucella lumazine synthase elicits a mixed Th1-Th2 immune response and reduces infection in mice challenged with Brucella abortus 544 independently of the adjuvant formulation used. Infect Immun, 2003, 71: 5750-5755

22 Teixeira-Gomes A P, Cloeckaert A, Bezard G, et al. Identification and characterization of Brucella ovis immunogenic proteins using two-dimensional electrophoresis and immunoblotting. Electrophoresis, 1997, 18: 1491-1497

23 Rafie-Kolpin M, Essenberg R C, Wyckoff J H 3rd. Identification and comparison of macrophage-induced proteins and proteins induced under various stress conditions in Brucella abortus. Infect Immun, 1996, 64: 5274-5283

24 Eschenbrenner M, Horn T A, Wagner M A, et al. Comparative proteome analysis of laboratory grown Brucella abortus 2308 and Brucella melitensis 16M. J Proteome Res, 2006, 5: 1731-1740

25 Lindler L E, Hadfield T L, Tall B D, et al. Cloning of a Brucella melitensis group 3 antigen gene encoding Omp28, a protein recognized by the humoral immune response during human brucellosis. Infect Immun, 1996, 64: 2490-2499

26 Rossetti O L, Arese A I, Boschiroli M L, et al. Cloning of Brucella abortus gene and characterization of expressed 26-kilodalton periplasmic protein: potential use for diagnosis. J Clin Microbiol, 1996, 34: 165-169

27 Sinha S, Kosalai K, Arora S, et al. Immunogenic membrane-associated proteins of Mycobacterium tuberculosis revealed by proteomics. Microbiology, 2005, 151: 2411-2419

28 Wehmhoner D, Dieterich G, Fischer E, et al. "LaneSpector", a tool for membrane proteome profiling based on sodium dodecyl sulfatepolyacrylamide gel electrophoresis/liquid chromatography-tandem mass spectrometry analysis: application to Listeria monocytogenes membrane proteins. Electrophoresis, 2005, 26: 2450-2460

29 Jubier-Maurin V, Boigegrain R A, Cloeckaert A, et al. Major outer membrane protein Omp25 of Brucella suis is involved in inhibition of tumor necrosis factor alpha production during infection of human macrophages. Infect Immun, 2001, 69: 4823-4830

30 Edmonds M D, Cloeckaert A, Booth N J, et al. Attenuation of a Brucella abortus mutant lacking a major $25 \mathrm{kDa}$ outer membrane protein in cattle. Am J Vet Res, 2001, 62: 1461-1466

31 Edmonds M D, Cloeckaert A, Elzer P H. Brucella species lacking the major outer membrane protein Omp25 are attenuated in mice and protect against Brucella melitensis and Brucella ovis. Vet Microbiol, 2002, 88: 205-221

32 Edmonds M D, Cloeckaert A, Hagius S D, et al. Pathogenicity and protective activity in pregnant goats of a Brucella melitensis Deltaomp25 deletion mutant. Res Vet Sci, 2002, 72: 235-239

33 Elzer P H, Phillips R W, Robertson G T, et al. The HtrA stress response protease contributes to resistance of Brucella abortus to killing by murine phagocytes. Infect Immun, 1996, 64: 4838-4841

34 Phillips R W, Elzer P H, Robertson G T, et al. A Brucella melitensis high-temperature-requirement $\mathrm{A}$ (htrA) deletion mutant is attenuated in goats and protects against abortion. Res Vet Sci, 1997, 63: 165-167

35 Kohler S, Ekaza E, Paquet J Y, et al. Induction of dnaK through its native heat shock promoter is necessary for intramacrophagic replication of Brucella suis. Infect Immun, 2002, 70: 1631-1634

36 Valent Q A, Kendall D A, High S, et al. Early events in preprotein recognition in E. coli: interaction of SRP and trigger factor with nascent polypeptides. EMBO J, 1995, 14: 5494-5505

37 Yang X, Walters N, Robison A, et al. Nasal immunization with recombinant Brucella melitensis bp26 and trigger factor with cholera toxin reduces B. melitensis colonization. Vaccine, 2007, 25: 22612268

Open Access This article is distributed under the terms of the Creative Commons Attribution License which permits any use, distribution, and reproduction in any medium, provided the original author(s) and source are credited. 